\title{
Human Papillomavirus Infection and Associated Risk Factors in Indigenous and Urban Women from Cañar Province, Ecuador
}

\author{
Julia Irma Carrión ${ }^{1}$, Yudira Soto ${ }^{2}$, Fabián Escandón ${ }^{3}$, Laura García-Pupo 4 and Maritza Pupo ${ }^{*}$ \\ ${ }^{1}$ Teaching and Research Department, Catholic University of Cuenca, Ecuador \\ ${ }^{2}$ Laboratory of Sexually Transmitted Diseases, Department of Virology, Institute of Tropical Medicine Pedro Kourí, Cuba \\ ${ }^{3}$ Humanity Hospital San José, Ecuador \\ ${ }^{4}$ Department of Neurochemistry, Cuban Center for Neurosciences, Cuba \\ ${ }^{5}$ Virology and Microbiology Department, Biology Faculty, Havana University, Cuba

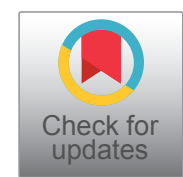

\begin{abstract}
Background: There are few studies about the circulation of Human Papillomavirus (HPV) in Ecuadorian women from Cañar province.

Objective: To determine HPV infection, circulating genotypes, viral load of the most frequent genotypes, intraepithelial cervical lesions and other cervical damages. Also, some social demographic, clinical and epidemiological behavior and its association with viral infection were analyzed.

Methods: Two groups of Ecuadorian women were included, indigenous from rural region and urban women, both from Cañar province. A descriptive cross-sectional study was conducted from July 2017 to September 2018. Two hundred endocervical cytological samples were collected from both women populations between 15 and 55 years of age, residing in this province. Samples were analyzed by Papanicolaou test and mucosal cells were submitted to DNA extraction and subsequently HPV detection and genotyping using a commercial kit CLART ${ }^{\circledR}$ HPV 2 (Genomic, Spain). The viral load from more frequent genotypes was determined by qPCR using the commercial kit HPV Genotypes 14 Real-TM Quant (Sacace, Biotechnologies Srl. Italy).
\end{abstract}

Results: Overall, infection frequency of HPV was $42.5 \%$ (85/200) with a predominance of oncogenic types, with a higher prevalence in women from urban area (51\%). Cervical intraepithelial lesions were detected in $11 \%(22 / 200)$ of cases, mostly low-grade lesions $(6 \% ; 12 / 200)$. HPV31, 58, 66 and 59 were the most frequently HPV detected, however HPV16 was higher frequency in rural women. The high-risk HPV viral load was higher in urban women, except for HPV16. There were significant differences between the means of viral load values when high and low grade cervical lesions were compared. Smoking, hormonal contraceptive use, and a history of sexually transmitted infections were factors associated with viral infection $(p<0.05)$. Differences between risk factors were observed between rural and urban women.

Conclusion: The high frequency of oncogenic HPV types detected indicates the need to incorporate the population of Cañar province into the early detection programs for cervical cancer and the vaccination program in Ecuador.

\section{Keywords}

Human papillomavirus, Papanicolaou test, Cervical intraepithelial lesions, DNA detection, HPV viral load, Sociodemographic, Epidemiological risk factors

\section{Introduction}

Human Papillomavirus (HPV) infection is the most frequent viral infection sexually transmitted in women and the third cause of cervical cancer [1]. Worldwide, 300 million people are estimated to carry HPV and among them nearly 500 000 women will develop cervical cancer, mainly in underdeveloped countries [2]. Therefore, current prevention strategies depend on periodic Papanicolaou (Pap) testing. However, the incorporation of the HPV DNA testing for cervical cancer screening has become advisable due to the low sensitivity of Pap testing and the importance of HPV [3]. The main risk
*Corresponding author: Dr. Maritza Pupo, Virology and Microbiology Department, Biology Faculty, Havana University, Street 25 e/n J \& I, Municipio Plaza de la Revolución. La Habana, Cuba, Tell: (537)-8321321; (537)-8329252l; (537)-8329251.

Accepted: November 30, 2020

Published online: December 02, 2020

Citation: Carrión JI, Soto Y, Escandón F, et al. (2020) Human Papillomavirus Infection and Associated Risk Factors in Indigenous and Urban Women from Cañar Province, Ecuador. J Cervical Cancer Res 3(1):307-317 
Citation: Carrión JI, Soto Y, Escandón F, et al. (2020) Human Papillomavirus Infection and Associated Risk Factors in Indigenous and Urban Women from Cañar Province, Ecuador. J Cervical Cancer Res 3(1):307-317

factors associated with HPV infection are sex, age, race, socio-demographic characteristics, prior sexually transmitted infections, parity, contraceptive methods, smoking and HPV oncogenic potential (low, high and intermediate risk types) [4].

In Ecuador, HPV epidemiology and cervical cancer prevalence are imprecise. Few epidemiological studies have been done in the last 20 years and most of them are based on diverse methods of detection and HPV genotyping. Therefore, there are discrepancies regarding to the prevalence of HPV genotype circulation [5]. However, there are reports about the high frequency of HPV 16 genotype followed by HPV 58 [6]. Concerning to cervical cancer (CC) it is the first most common cancer among women at reproductive age and the highest incidence rates are observed in the 40 to 64 year-age group. The National Cancer Registry from Ecuador revealed that the incidence rates are not homogeneous throughout the country, with the highest incidence rates observed in Cuenca city and the lowest in Quito [7,8]. Although these results came from studies in women populations, covering different areas of Ecuador, such as coastal, littoral and southern regions, only urban cohorts were included $[5,9,10]$. Then, the present work provides further insights in HPV prevalence in both indigenous and urban women populations, from Cañar province. Therefore our results may contribute to a better understanding of HPV epidemiology in Ecuador.

\section{Materials and Methods}

\section{Study design and population}

A cross-sectional study was conducted from July 2017 to September 2018 in Cañar province, Ecuador. The studied population using an opportunistic patient selection method, and comprised all women between 15 and 55 years old, who agreed to participate and accomplished the inclusion criteria. In total 200 women were selected, 100 from a rural community and 100 from the urban community of Cañar province, Ecuador. Women from rural community were indigenous-Quechua ethnicity as much as socio-cultural and linguistic point of view; meanwhile those from urban community were mainly mestizos.

As exclusion criteria, pregnancy, the use of medical treatments or exposure to gynecological procedures three months before the research and having sexual relationships or genital touch 48 hours before the test, were considered. Other exclusion criteria included the use of some drugs which can affect the results of the cytological test or viral detection as colchicine, estrogens, podophyllin, progestagens and silver nitrate use [11].

Once participants agreeing to contribute through, written informed consent they fulfilled a questionnaire including variables to be studied as age, ethnicity, habits such as smoking, drugs and alcohol use. Other questions included gynecological and obstetrical background, the use of contraceptive methods, sexual practices, lifetime and current sexual partners, and history of sexual transmitted infections (STI). This questionnaire was completed under the supervision of the researcher in charge of the study who checked that the informed consent form was signed properly.
Once all the requirements were achieved, a personal interview was performed with each participant, together with a gynecologist, a psychologist, a lawyer and the researcher in charge of the study.

Cervical swabs was collected from each woman in order to determine HPV infection, circulating genotypes, viral load of the most frequent genotypes, intraepithelial cervical lesions and other cervical damages. Also, some socio-demographic, clinical and epidemiologic behavioral factors and its association with viral infection were analyzed.

\section{Ethical requirements}

Women attended to the announcement through divulging from local church of Cañar, meeting with community leaders, warnings, dispatches disposed in free places of the community keeping the ethical and lawful aspects. Participants were informed about the advantages of the study and they could withdraw from the study at any time. Informed consent was obtained before the collection of the cervical specimens. All procedures were in accordance with the Helsinki Declaration and International Ethical WHO-CIOMS [12].

\section{Clinical samples and Pap test}

Cervical cells were collected for liquid-based preparations by brushing into endocervical canal to obtain endo and exo cervical cells. Pap test was interpreted once and at later time by three different observers, who were cytology trained technicians. Smears for cyto-morphological analysis were classified as useful according to Bethesda System 2014 [13]. Cells were kept in commercial solution of Sure Path (Becton Dickinson, Sparks, MD, USA) at - 20 ㅇ until DNA extraction for HPV detection and typing.

\section{DNA extraction}

Cellular suspensions were homogenized by vigorous stir and DNA extraction was performed using commercial QIAamp ${ }^{\circledR}$ DNA Mini Kit (QIAGEN, Hilden, Germany) according to the manufacturer's protocol. Purification yielded between 50 to $100 \mathrm{ng} / \mu \mathrm{L}$ DNA per sample, which was diluted in $100 \mu \mathrm{L}$ of elution buffer and stored at $-20 \stackrel{\circ}{ }{ }^{\circ}$ until next use.

\section{Detection and genotyping of HPV}

Detection and genotyping of HPV samples collected was achieved using low density microarrays by the commercial kit CLART ${ }^{\circledR}$ HPV 2 (IVD, registered Trademark of GENOMICA, Spain), following manufacturer's instructions. Briefly, a 450 bp fragment into ORF L1 from viral genome was amplified to hybridize with specific primers per each genotype. Amplification reactions were performed with $5 \mu \mathrm{L}$ of purified DNA from each clinical simple. Each microarray included an internal DNA control from the clinical sample, an external amplification control and a control for marking and visualization of the amplified products. This assay detects 35 genotypes of HPV, most of which are of clinical importance, such as 15 low risk (LR-HPV) types $(6,11,40,4$ 2, 43, 44, 54, 61, 62, 71, 72, $81,83,84,85$ and 89$)$ and 20 high-risk or probably high-risk HPV (HR-HPV) types $(16,18,26,31,33,35,39,45,51,52,53$, $56,58,59,66,68,70,73$ and 82 ) according to International 
Citation: Carrión JI, Soto Y, Escandón F, et al. (2020) Human Papillomavirus Infection and Associated Risk Factors in Indigenous and Urban Women from Cañar Province, Ecuador. J Cervical Cancer Res 3(1):307-317

Agency for Research on Cancer criteria [14].

\section{Viral load of HR-HPV}

The viral load of most frequent HR-HPV types detected in both groups of women were determined by quantitative real-time PCR (qRT-PCR) using the commercial kit HPV Genotypes 14 Real-TM Quant (Sacace Biotechnologies Srl, Italy, REF V67-100FRT) according to manufacturer's instructions. Four multiplex PCR reactions were performed for each clinical sample. Controlling DNA quality $\beta$-globin was amplified from each sample. Each genotype was detected in one fluorescent channel (FAM, JOE, ROX y Cy5). The assay had a detection limit from 10 to 100 million copies of HPV DNA for all genotypes. Clinical samples quantification was established according to standard reference values from $10^{4}$ to $10^{7}$ copies $/ \mathrm{mL}$, for all genotypes and internal control in the assay. Assay and analysis were performed in Rotor-Gene ${ }^{\circledR} \mathrm{Q}$ (QIAGEN, Hilden, Germany) equipment, RT-PCR program following manufacturer's instructions of commercial kit HPV Genotypes 14 Real-TM Quant.

\section{Data Analysis}

All personal data, including clinical, epidemiological and laboratory results from each patient were stored in an Excel database with a code in order to keep the confidentiality. Variables analyses were performed by the statistical package SPSS version 19.0 (IBM Inc., Berkeley, CA, USA). Proportions were analyzed by contingence tables and Chi-square test. Odds ratios (OR) and $95 \%$ confidence intervals $(\mathrm{Cl})$ were calculated in a univariate logistic regression to estimate the association of socio-demographic, clinical and epidemiological variables and HPV infections. In order to predict a potential relationship between viral load of the most frequent HR-HPV genotypes in clinical samples and others variables of interest, the statistical package Graph Pad Prism 3.0 was used. Kruskall-Wallis and Mann Whitney tests were used to compare viral load medians.

\section{Results}

The minority of indigenous women interviewed recognized HPV infection as a cause of CC, contrarily to the most urban women. Indigenous women also ignored cytology as a diagnostic tool for HPV detection and most of them revealed had not been tested before our cytology study.

The median of age from the general studied women population was 40 years old and the higher percentage cor-

Table 1: Socio-demographic characteristics of the studied population

\begin{tabular}{|c|c|c|c|c|}
\hline Variables & Groups or ranges & $\begin{array}{l}\text { Urban women } \\
N=100 \\
(n=\%)^{*}\end{array}$ & $\begin{array}{l}\text { Indigenous women } \\
\mathrm{N}=100 \\
(\mathrm{n}=\%)^{*}\end{array}$ & $\begin{array}{l}\text { Total } \\
\mathbf{N}=\mathbf{2 0 0} \\
\mathbf{N}(\%)\end{array}$ \\
\hline Indigenous Ethnicity Quechua & $\begin{array}{l}\text { Yes } \\
\text { No }\end{array}$ & $\begin{array}{l}0 \\
100\end{array}$ & $\begin{array}{l}100 \\
0\end{array}$ & $\begin{array}{l}100(50) \\
100(50)\end{array}$ \\
\hline $\begin{array}{l}\text { Age ranges (in years) } \\
\text { Median }=40 \text { years }\end{array}$ & $\begin{array}{l}<20 \\
20-30 \\
31-40 \\
41-50 \\
>50\end{array}$ & $\begin{array}{l}1 \\
26 \\
27 \\
34 \\
12\end{array}$ & $\begin{array}{l}2 \\
24 \\
27 \\
27 \\
20\end{array}$ & $\begin{array}{l}3(1.5) \\
50(25) \\
54(27) \\
61(30.5) \\
32(16)\end{array}$ \\
\hline Education level & $\begin{array}{l}\text { Illiteracy } \\
\text { Primary } \\
\text { Secondary } \\
\text { University }\end{array}$ & $\begin{array}{l}4 \\
36 \\
35 \\
25\end{array}$ & $\begin{array}{l}37 \\
50 \\
10 \\
3\end{array}$ & $\begin{array}{l}41(20.5) \\
86(43) \\
45(22.5) \\
28(14)\end{array}$ \\
\hline Occupation & $\begin{array}{l}\text { Student } \\
\text { Housework } \\
\text { Agriculture } \\
\text { Laborer } \\
\text { Professional }\end{array}$ & $\begin{array}{l}11 \\
42 \\
9 \\
26 \\
12\end{array}$ & $\begin{array}{l}3 \\
32 \\
58 \\
6 \\
1\end{array}$ & $\begin{array}{l}14(7) \\
74(37) \\
67(33.5) \\
32(16) \\
13(6.5)\end{array}$ \\
\hline Marital status & $\begin{array}{l}\text { Married } \\
\text { Single } \\
\text { Divorce } \\
\text { Consensual union }\end{array}$ & $\begin{array}{l}11 \\
42 \\
9 \\
26\end{array}$ & $\begin{array}{l}3 \\
32 \\
58 \\
6\end{array}$ & $\begin{array}{l}14(7) \\
74(37) \\
67(33.5) \\
32(16)\end{array}$ \\
\hline Smoking & Yes & 32 & 0 & $32(16)$ \\
\hline Alcohol consuming & Yes & 1 & 2 & $3(1.5)$ \\
\hline Drugs consuming & Yes & 0 & 0 & $0(0)$ \\
\hline Healthy Food ingesting & Yes & 68 & 82 & $150(75)$ \\
\hline
\end{tabular}

Source: Inquiry form. ${ }^{*} \mathrm{n}=\%$ because $\mathrm{n}=100$ 
Citation: Carrión JI, Soto Y, Escandón F, et al. (2020) Human Papillomavirus Infection and Associated Risk Factors in Indigenous and Urban Women from Cañar Province, Ecuador. J Cervical Cancer Res 3(1):307-317

responded to the group of 41 to 51 years old. Illiteracy was predominant in indigenous women meanwhile women residing in urban areas had higher percentage of instruction level. Regarding to occupation status, it was superior in urban population similar to homemaker's percentage. Women from rural areas were mainly agriculturist. Most of women from both areas were married being higher in rural women who also had healthy alimentary but not smoking habits. Epidemiological and socio-demographics data are shown in Table 1.

Sexual history and gynecological data showed that, the majority of women had the menarche before 14 years old and began sexual relationship among 16 to 20 years old. About $50 \%$ had more than one pregnancy and delivery during their reproductive live; meanwhile $92 \%$ performed an abortion in the same period. Concerning to sexual partner, $82 \%$ mentioned just one partner in the last 2 years and $50 \%$ of these women were examined by cervical cytology test sometime in their sexually active live. Table 2 shows sexual history and gynecological data from examined women.

In almost $50 \%$ of cases, inflammatory process were de-

Table 2: Sexual history and gynecological data of the studied population.

\begin{tabular}{|c|c|c|c|c|}
\hline \multicolumn{2}{|l|}{ Variables } & \multirow{2}{*}{$\begin{array}{l}\text { Urban women } \\
N=100 \\
\text { (n=\%) } \\
83 \\
17\end{array}$} & \multirow{2}{*}{$\begin{array}{l}\text { Indigenous women } \\
N=100 \\
\text { ( } n=\%) \\
92 \\
8\end{array}$} & \multirow{2}{*}{$\begin{array}{l}\text { Total } \\
\mathbf{N}=\mathbf{2 0 0} \\
\mathbf{N}(\%) \\
175(87.5) \\
25(12.5)\end{array}$} \\
\hline $\begin{array}{l}\text { Age of menarche } \\
\text { (in years) }\end{array}$ & $\begin{array}{l}\leq 14 \\
\geq 15\end{array}$ & & & \\
\hline $\begin{array}{l}\text { Age of first sexual intercourse (in } \\
\text { years) }\end{array}$ & $\begin{array}{l}\leq 15 \\
16-20 \\
>20\end{array}$ & $\begin{array}{l}3 \\
84 \\
13\end{array}$ & $\begin{array}{l}2 \\
81 \\
17\end{array}$ & $\begin{array}{l}5(2.5) \\
165(82.5) \\
30(15)\end{array}$ \\
\hline Number of pregnancies & $\begin{array}{l}0-1 \\
2-3 \\
\geq 4\end{array}$ & $\begin{array}{l}20 \\
52 \\
28\end{array}$ & $\begin{array}{l}10 \\
45 \\
45\end{array}$ & $\begin{array}{l}30(15) \\
97(48.5) \\
73(36.5)\end{array}$ \\
\hline Number of deliveries & $\begin{array}{l}0-1 \\
2-3 \\
\geq 4\end{array}$ & $\begin{array}{l}25 \\
54 \\
21\end{array}$ & $\begin{array}{l}13 \\
52 \\
35\end{array}$ & $\begin{array}{l}38(19) \\
106(53) \\
56(28)\end{array}$ \\
\hline Number of induced abortions & $\begin{array}{l}0-1 \\
\geq 2\end{array}$ & $\begin{array}{l}93 \\
7\end{array}$ & $\begin{array}{l}92 \\
8\end{array}$ & $\begin{array}{l}185(92.5) \\
15(7.5)\end{array}$ \\
\hline $\begin{array}{l}\text { Number of sexual partners in last } \\
2 \text { years }\end{array}$ & $\begin{array}{l}1 \\
2-3 \\
\geq 4\end{array}$ & $\begin{array}{l}86 \\
11 \\
3\end{array}$ & $\begin{array}{l}78 \\
22 \\
0\end{array}$ & $\begin{array}{l}164(82) \\
33(16.5) \\
3(1.5)\end{array}$ \\
\hline $\begin{array}{l}\text { Cervical cytology sometime in } \\
\text { sexually active life }\end{array}$ & Yes & 73 & 27 & $100(50)$ \\
\hline Cervical cytology in last 5 years & Yes & 44 & 24 & $64(32)$ \\
\hline $\begin{array}{l}\text { Inflammatory processes in cervical } \\
\text { cytology }\end{array}$ & Yes & 52 & 45 & $97(48.5)$ \\
\hline $\begin{array}{l}\text { Degree of inflammation of cervical } \\
\text { mucosa }\end{array}$ & $\begin{array}{l}\text { Mild } \\
\text { Moderate } \\
\text { Severe }\end{array}$ & $\begin{array}{l}19 \\
22 \\
11\end{array}$ & $\begin{array}{l}21 \\
18 \\
6\end{array}$ & $\begin{array}{l}40(20) \\
40(20) \\
17(8.5)\end{array}$ \\
\hline Cervical atrophy & Yes & 19 & 25 & $43(21.5)$ \\
\hline Previous history of STI & Yes & 35 & 42 & $77(38.5)$ \\
\hline Habitual use of condom & Yes & 4 & 4 & $8(4)$ \\
\hline Hormonal contraceptive use & Yes & 55 & 45 & $100(50)$ \\
\hline $\begin{array}{l}\text { Hormonal contraceptive use (in } \\
\text { years) }\end{array}$ & $\begin{array}{l}1 \\
2-4 \\
\geq 5\end{array}$ & $\begin{array}{l}6 \\
31 \\
18\end{array}$ & $\begin{array}{l}13 \\
23 \\
9\end{array}$ & $\begin{array}{l}19(9.5) \\
54(27) \\
25(12.5)\end{array}$ \\
\hline Gynecological symptoms* & $\begin{array}{l}\text { Vaginal discharge } \\
\text { Pruritus } \\
\text { Metrorrhagia } \\
\text { None }\end{array}$ & $\begin{array}{l}60 \\
12 \\
20 \\
8\end{array}$ & $\begin{array}{l}72 \\
10 \\
7 \\
22\end{array}$ & $\begin{array}{l}132(66) \\
22(11) \\
27(13.5) \\
30(15)\end{array}$ \\
\hline
\end{tabular}

Source: Inquiry form. *It can be appeared several gynecological symptoms in the same patient; STI: Sexually Transmitted Infections. 
Citation: Carrión JI, Soto Y, Escandón F, et al. (2020) Human Papillomavirus Infection and Associated Risk Factors in Indigenous and Urban Women from Cañar Province, Ecuador. J Cervical Cancer Res 3(1):307-317

tected during cytological study, $21 \%$ showed cervical atrophy and $38 \%$ had previous STI. Regarding contraception, $50 \%$ of women referred the use of hormonal contraceptive use and $4 \%$ admitted to be non-condom users.

\section{Pap test results}

According to the observers in the last Pap examination, from 200 women examined $89 \%$ (178/200) were negative for malignancy and $11 \%(22 / 200)$ showed cervical intraepithelial lesions. From these, 54.5\% (12/22) had LSIL, 27.3\% (6/22) had AS-CUS and $18.2 \%$ (4/22), HSIL. There were minor differences between both groups; urban and rural (See Table 3).

Quality control for Pap test was $100 \%$ satisfactory for samples adequacy, in both groups of studied women. There were differences at first Pap examination for both groups as previously reported $[15,16]$. From indigenous women $92 \%$ of samples were negative for malignity and $8 \%$ showed cytological changes. From negative cytology $23.9 \%$ (22/92) did not revealed any benign change and 48\% (45/92) had an inflammatory pattern, mainly light inflammation (21/45), over moderate $(18 / 45)$ or severe $(6 / 45)$. Of these women $27.2 \%$ (25/92) showed cervical atrophy, mainly women aged $\geq 40$ years.

In women who residing in urban area, the $86 \%$ of samples was negative for malignity and in the $14 \%$ cytological changes were displayed. There was not any kind of benign cytological changes in the $21 \%(18 / 86)$ of negative cytology for malignity. However, the $60.5 \%(52 / 86)$ of these women had some inflammatory pattern (22/52) mainly mild inflammation. Light $(19 / 52)$ and sever inflammations (11/52) were less frequent. Twenty two percent (19/86) exhibited cervical atrophy, only in women aged $\geq 40$ years.

\section{HPV infection}

The infection frequency (IF) of HPV among all studied women was $42.5 \%$ (85/200) and 26 different genotypes were identified, most of them oncogenic. From HR-HPV types, the HPV 31 was the most frequently detected, as it represented $50.6 \%$ (43/85) from all positives cases, followed by HPV 58 , which represented 32.9\% (28/85). Genotypes 66 and 59 were detected in $24.7 \%$ (21/85) and $16.5 \%$ (14/85) of all positives cases, respectively. LR-HPV genotypes were identified in 54.1\% (46/85), mainly HPV 61 (23.5\%; 20/85). Confections with several HPV genotypes were detected in $50.6 \%$ (43/85) of cases, mostly with more than 3 types (Figure 1 ).

The IF of HPV for each group was studied previously by Carrión et al. Indigenous women showed an IF of $34 \%$ with one or more genotypes. Twelve genotypes were recognized being the oncogenic types predominated [16]. Moreover, urban women had higher IF of $51 \%$, as well as more genotypes detected (26 different genotypes) [17].

Table 3: Distribution of cervical lesions in both groups of studied women.

\begin{tabular}{|l|l|l|l|}
\hline Lesions & $\begin{array}{l}\text { Urban } \\
\mathbf{n = 1 0 0}\end{array}$ & $\begin{array}{l}\text { Rural } \\
\mathbf{n = 1 0 0}\end{array}$ & Total = 200 \\
\hline AS-CUS & 4 & 2 & 6 \\
\hline LSIL & 7 & 5 & 12 \\
\hline HSIL & 3 & 1 & 4 \\
\hline Total & 14 & 8 & 22 \\
\hline
\end{tabular}

ASC-US: Atypical Squamous Cells of Undetermined Significance; LSIL: Low Grade Squamous Intraepithelial Lesion; HSIL: High Grade Squamous Intraepithelial Lesion

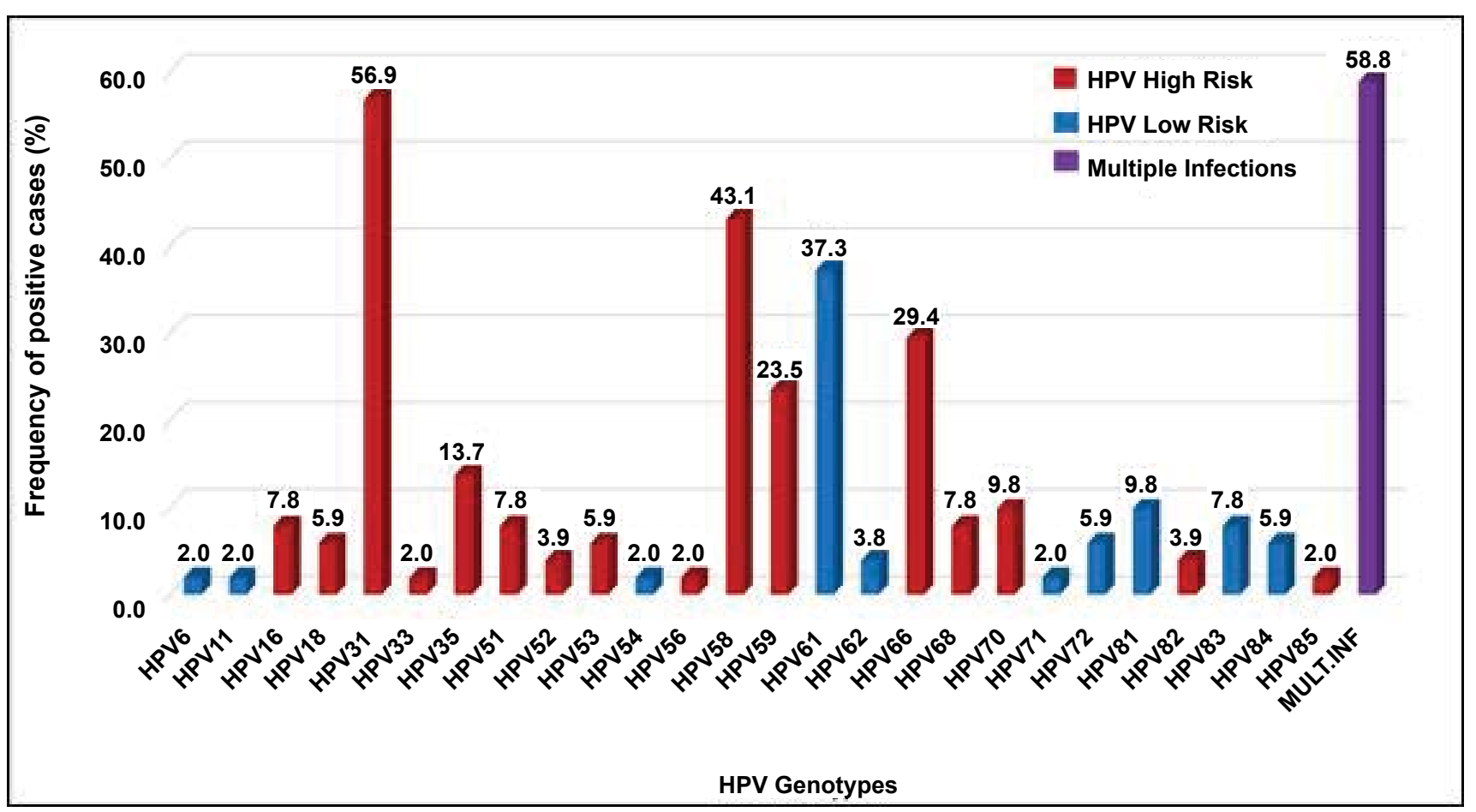

Figure 1: HPV Infection in women from Cañar, Ecuador. 
Citation: Carrión JI, Soto Y, Escandón F, et al. (2020) Human Papillomavirus Infection and Associated Risk Factors in Indigenous and Urban Women from Cañar Province, Ecuador. J Cervical Cancer Res 3(1):307-317

Table 4: Socio-demographic, clinic and epidemiological variables associated with HPV infection in women from Cañar province, Ecuador.

\begin{tabular}{|c|c|c|c|c|c|c|c|c|}
\hline Variables & Groups or ranges & & $\begin{array}{l}\text { tal } \\
200\end{array}$ & & & $\begin{array}{c}\text { Chi square test } \\
\mathrm{X}^{2}\end{array}$ & p Value & OR (Cl 95\%) \\
\hline & & $\mathbf{n}$ & $\%$ & $\mathbf{n}$ & $\%$ & & & \\
\hline Women classification & Indigenous & 100 & 50 & 34 & 40 & 5.91 & 0.011 & $2.02(1.14-3.57)$ \\
\hline & Urban & 100 & 50 & 51 & 60 & & & \\
\hline Indigenous Ethnicity Quechua & Yes & 100 & 50 & 31 & 36.5 & 10.82 & 0.001 & $0.38(0.21-0.68)$ \\
\hline Age ranges & $<20$ & 3 & 1.5 & 3 & 3.5 & 4.12 & 0.075 & $0.42(0.35-0.49)$ \\
\hline (in years) & $20-30$ & 50 & 25 & 28 & 32.9 & 4.97 & 0.020 & $2.08(1.09-3.97)$ \\
\hline & $31-40$ & 54 & 27 & 26 & 30.6 & 0.97 & 0.205 & $1.37(0.73-0.27)$ \\
\hline & $41-50$ & 61 & 30.5 & 23 & 27.1 & 0.82 & 0.226 & $0.75(0.41-1.39)$ \\
\hline & $>50$ & 32 & 16 & 5 & 5.9 & 11.26 & 0.000 & $0.20(0.07-0.55)$ \\
\hline Occupation & Student & 14 & 7 & 9 & 10.6 & 2.92 & 0.070 & $2.60(0.84-8.08)$ \\
\hline & Homemaker & 74 & 37 & 27 & 31.8 & 1.74 & 0.121 & $0.67(0.37-1.21)$ \\
\hline & Farmer & 67 & 33.5 & 24 & 28.2 & 1.84 & 0.114 & $0.66(0.36-1.21)$ \\
\hline & Laborer & 32 & 16 & 16 & 18.8 & 0.88 & 0.229 & $1.44(0.67-3.08)$ \\
\hline & Professional & 13 & 6.5 & 9 & 10.6 & 4.06 & 0.043 & $3.29(1.01-11.06)$ \\
\hline Education Level & Illiteracy & 41 & 20.5 & 14 & 16 & 1.47 & 0.150 & $0.64(0.31-1.32)$ \\
\hline & Primary & 86 & 43 & 33 & 38.8 & 1.05 & 0.189 & $0.74(0.42-1.31)$ \\
\hline & Secondary & 45 & 22.5 & 20 & 23.5 & 0.09 & 0.447 & $1.11(0.57-2.16)$ \\
\hline & University & 28 & 14 & 18 & 21.2 & 6.32 & 0.011 & $2.82(1.23-6.48)$ \\
\hline Marital status & Married & 138 & 69 & 50 & 58.8 & 7.16 & 0.006 & $0.44(0.24-0.82)$ \\
\hline & Single & 27 & 13.5 & 21 & 24.7 & 15.9 & 0.000 & $5.96(2.29-15.54)$ \\
\hline & Divorced & 9 & 4.5 & 4 & 4.7 & 0.01 & 0.582 & $1.09(0.28-4.17)$ \\
\hline & Consensual join & 19 & 9.5 & 9 & 10.6 & 0.20 & 0.414 & $1.24(0.48-3.21)$ \\
\hline & Widow & 7 & 3.5 & 1 & 1.2 & 2.36 & 0.124 & $0.22(0.02-1.83)$ \\
\hline Age of menarche & $\leq 14$ & 185 & 92.5 & 82 & 96.5 & 10.88 & 0.001 & $6.47(1.87-22.40)$ \\
\hline (in years) & $\geq 15$ & 25 & 12.5 & 3 & 3.5 & 10.88 & 0.001 & $0.16(0.05-0.54)$ \\
\hline Age of first sexual intercourse & $\leq 15$ & 5 & 2.5 & 4 & 4.7 & 2.95 & 0.105 & $5.63(0.62-51.30)$ \\
\hline (in years) & $16-20$ & 165 & 82.515 & 74 & 87.1 & 2.13 & 0.101 & $1.77(0.82-3.86)$ \\
\hline & $>20$ & 30 & & 7 & 8.2 & 5.31 & 0.016 & $0.36(0.15-0.88)$ \\
\hline Number of pregnancies & $0-1$ & 30 & 15 & 16 & 18.8 & 1.69 & 0.136 & $0.167(0.77-3.65)$ \\
\hline & $2-3$ & 97 & 48.5 & 47 & 55.3 & 2.73 & 0.065 & $1.61(0.91-2.83)$ \\
\hline & $\geq 4$ & 73 & 36.5 & 22 & 25.9 & 7.19 & 0.005 & $0.44(0.24-0.81)$ \\
\hline Number of deliveries & $0-1$ & 38 & 19 & 20 & 23.5 & 1.97 & 0.111 & $1.66(0.82-3.37)$ \\
\hline & $2-3$ & 106 & 53 & 50 & 58.8 & 2.01 & 0.101 & $1.51(0.86-2.65)$ \\
\hline & $\geq 4$ & 56 & 28 & 15 & 17.6 & 7.86 & 0.004 & $0.39(0.19-0.76)$ \\
\hline Previous history of STI & Yes & 77 & 38.5 & 43 & 50.6 & 9.12 & 0.002 & $2.44(1.36-4.37)$ \\
\hline Smoking & Yes & 32 & 16 & 24 & 28.2 & 16.47 & 0.000 & $5.26(2.23-12.43)$ \\
\hline $\begin{array}{l}\text { Inflammation process in } \\
\text { cervical cytology }\end{array}$ & Yes & 97 & 48.5 & 51 & 60 & 7.83 & 0.004 & $2.25(1.27-3.99)$ \\
\hline Degree of inflammation of & Mild & 40 & 20 & 19 & 22 & 0.51 & 0.295 & $1.29(0.64-2.58)$ \\
\hline cervical mucosa & Moderate & 41 & 20.5 & 23 & 27.1 & 3.90 & 0.037 & $2.00(1.01-4.00)$ \\
\hline & Severe & 25 & 12.5 & 15 & 17.6 & 3.60 & 0.048 & $2.25(1.00-5.29)$ \\
\hline Gynecological symptoms & Vaginal discharge & 132 & 66 & 65 & 76.5 & 7.22 & 0.005 & $2.33(1.25-4.34)$ \\
\hline Hormonal contraceptive use & Yes & 100 & 50 & 51 & 60 & 5.91 & 0.011 & $2.02(1.14-3.56)$ \\
\hline Hormonal contraceptive use & 1 & 19 & 9.5 & 13 & 15.3 & 5.77 & 0.016 & $3.28(1.19-9.53)$ \\
\hline & $2-4$ & 54 & 27 & 28 & 32.9 & 2.65 & 0.072 & $1.68(0.90-3.15)$ \\
\hline & $\geq 5$ & 27 & 13.5 & 10 & 11.8 & 0.38 & 0.344 & $0.77(0.33-1.78)$ \\
\hline
\end{tabular}

Source: Inquiry form and statistical analysis. STI: Sexually transmitted infections. 


\section{HPV infections and cytological findings}

Of the 22 women with cytological changes, all of them were infected with HPV. In LSIL, HPV 31, 16 and 58 were the most prevalent genotypes. HPV 16 seems more directly associated with HSIL, representing $75 \%$ (3/4) of all cases (See Table 4).

\section{Viral load of HR-HPV types}

Medians viral load were over than 1000 copies/mL, for all HR-HPV genotypes detected in infected women. HPV 53 showed the lowest viral load. However, statistical differences were not observed (Figure 2A). HR-HPV types viral load were significantly higher in urban women, over $10^{6}$ copies $/ \mathrm{mL}, \mathrm{p}<$ 0.0001 , compared to women from the rural community (Figure $2 \mathrm{~B})$. On the contrary, HPV 16 viral load from rural women was significantly higher ( $>10^{6}$ copies $/ \mathrm{mL}, \mathrm{p}=0.0021$ ), compared to urban women (Figure 2C).

Genotypes 31 and 58 were the most frequently detected and the median viral loads were significantly higher in urban $\left(10^{6}\right.$ and $10^{7}$ copies $/ \mathrm{mL}$ ) (Figure $3 \mathrm{~A}$ and Figure $3 \mathrm{~B}$ ) followed by HPV 59 and 66 (Figure 4A and Figure 4B).
HPV 35 was only circulating in urban women, meanwhile viral load of HPV 18 and 53 were not different in both groups, with high values from $10^{7}$ to $10^{8}$ copies $/ \mathrm{mL}$.

The median viral loads showed differences according to cytological diagnosis, $p=0.0020$ (See Figure 5). HR-HPV viral loads were significantly higher in HSIL cases compared to LSIL cases ( $p=0.0009)$. All cases with cytological changes had significantly high viral loads compared with women who had negative cytology $(p<0.001)$.

\section{Clinical, epidemiological and socio-demographic factors associated to HPV infection}

Variables associated to HPV infection in studied women are shown in Table 4. There were significant differences in IF of HPV when both groups of women (rural and urban) were compared, being higher in women between $20-30$ years old and lower in those with more than 50 years.

The risk of HPV infection was increased in single women, in those who had menarche before 14 years old and women with previous STI. Women who referred smoking habit had 5

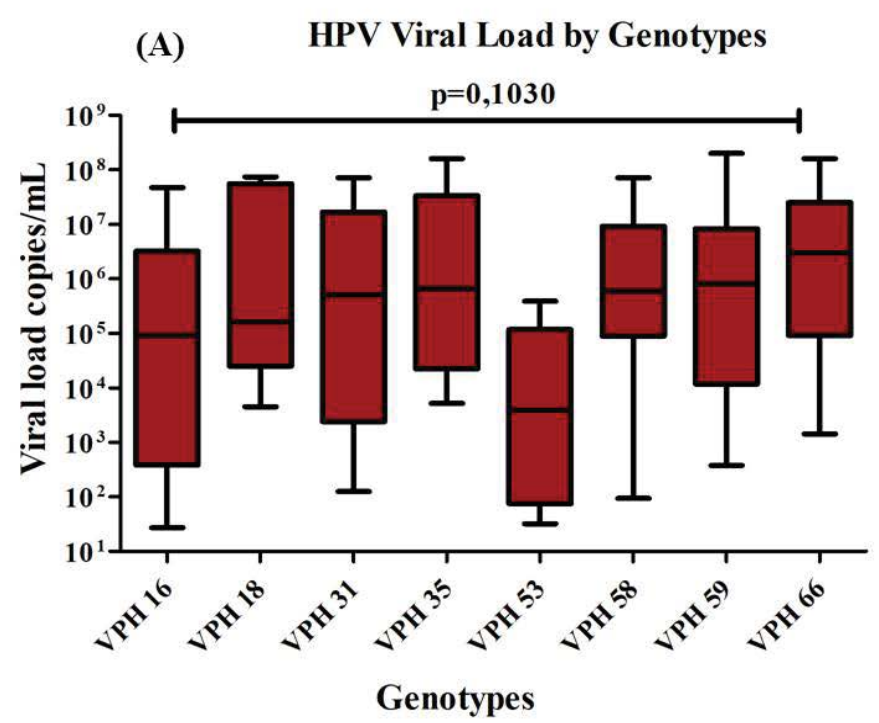

(B) HPV Viral Load by Group of Women

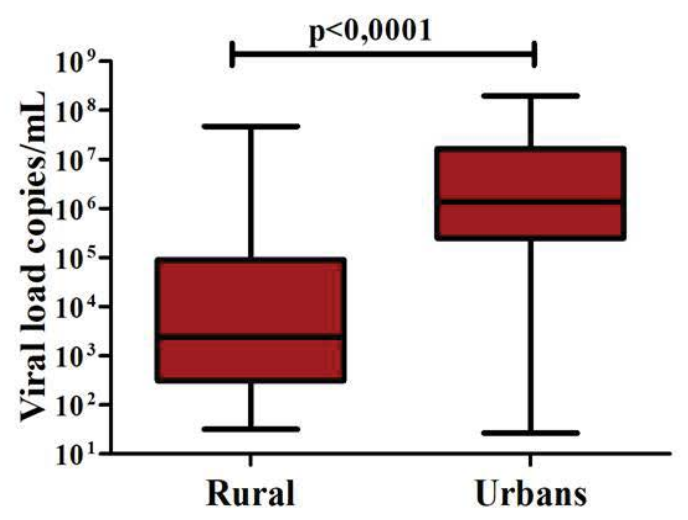

(C) HPV 16 Viral Load by Group of Women

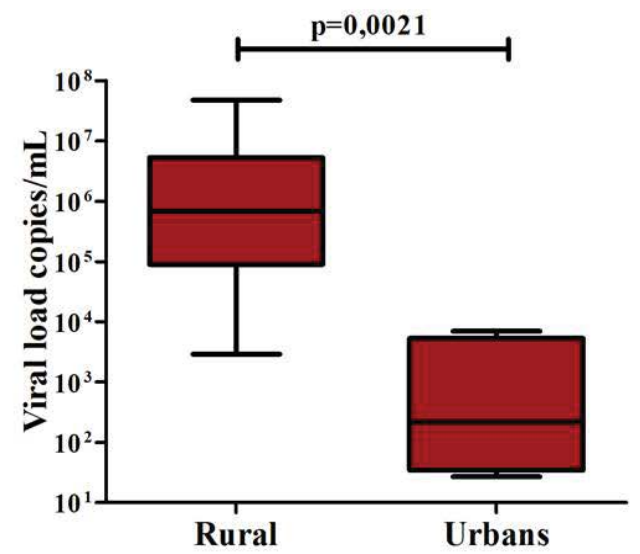

Figure 2: Comparison of the median viral load of HR-HPV types A) Rural and urban women from Cañar; B) HPV infection in both groups of women; C) HPV 16 in both groups of women. 
(A) HPV 31 Viral Load by Group of Women

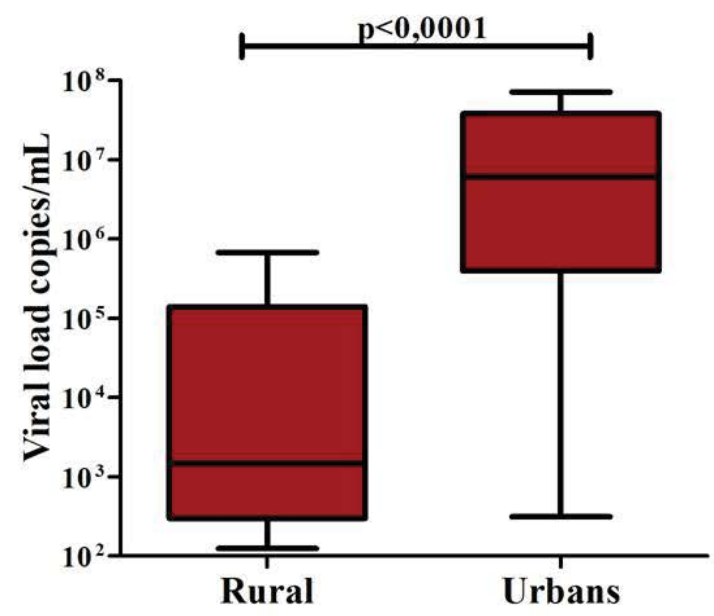

(B) HPV 58 Viral Load by Group of Women

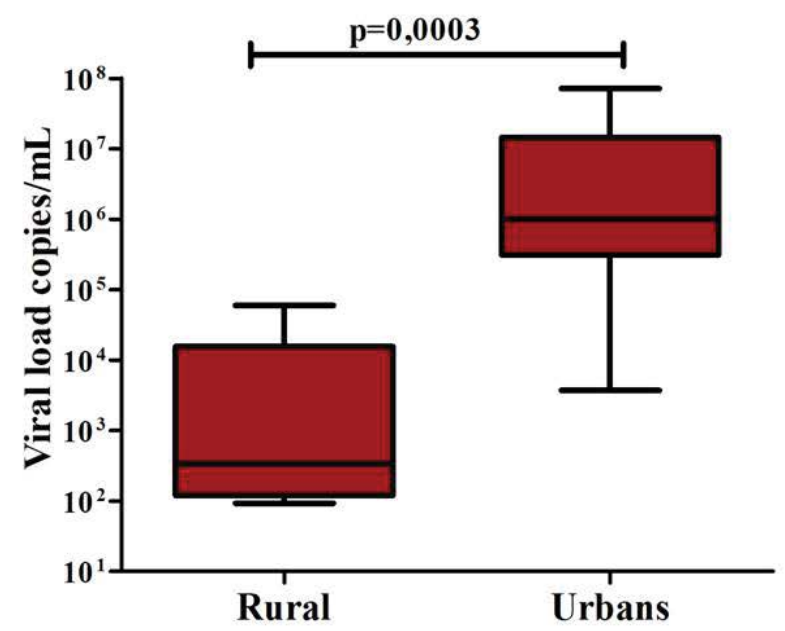

Figure 3: Comparison of the median viral load A) HPV 31 and B) HPV 58 between rural and urban women from Cañar.

HPV 59 Viral Load by Group of Women

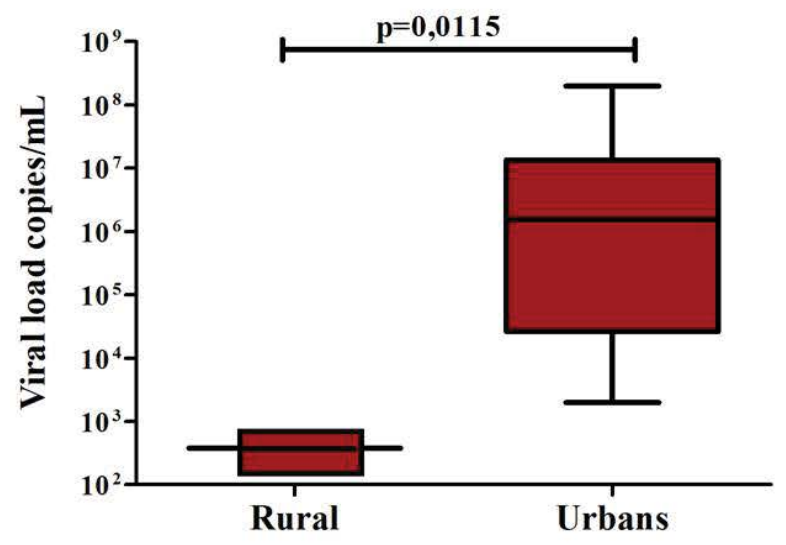

HPV 66 Viral Load by Group of Women

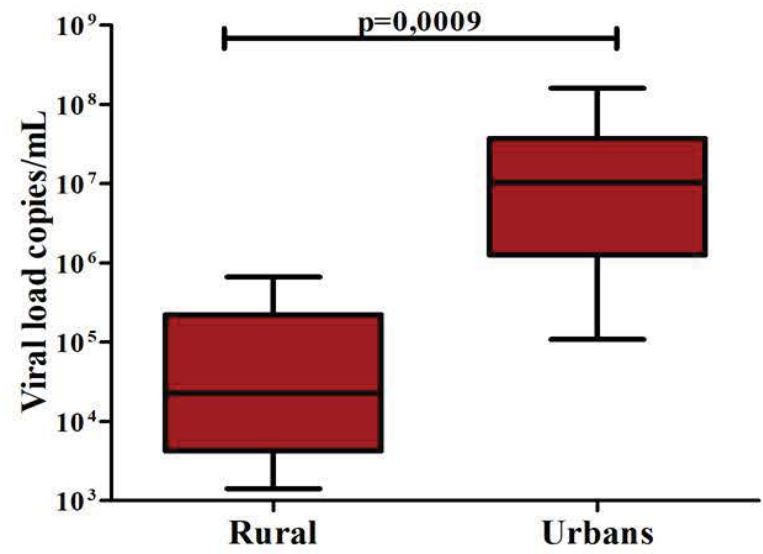

Figure 4: Comparison of the median viral load A) HPV 59 and B) HPV 66 between rural and urban women from Cañar.

HPV Viral Load by Lesions

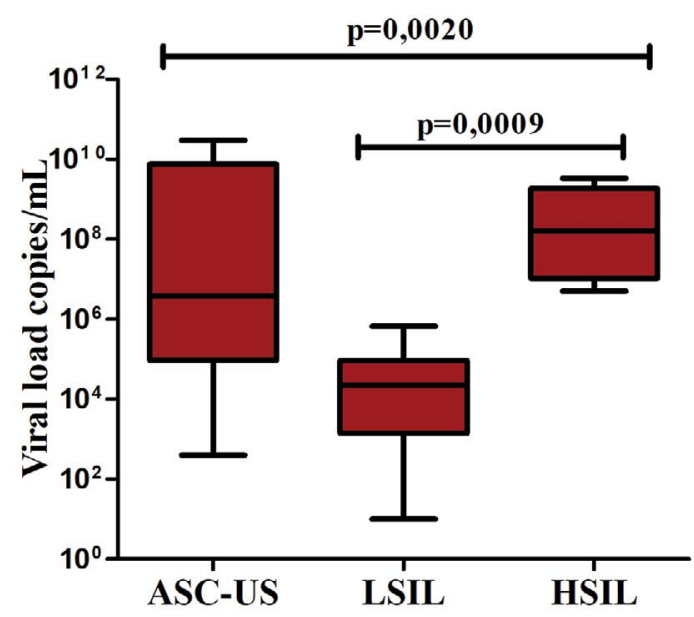

Figure 5: Comparison of median viral loads of HR-HPV regarding to cytological diagnosis in women from Cañar province more times probabilities to be HPV infected. Moderate and severe inflammatory process in cervical mucosa were associated with viral infection as same as pathological gynecological symptoms as vaginal discharge. Women who referred the used of hormonal contraceptive methods showed a major risk of HPV infection (Table 4).

Analysis of variables in women from rural area showed that the group between $20-30$ years old $(44.1 \%$; $15 / 34)$ had 5 times more probabilities to get HPV infection than women from other age groups. In single women the IF of HPV was higher, also in those with 2 or 3 pregnancies and similar deliveries number. Also, previous sexual history was a variable associated to HPV infection (Table 4).

A protective effect to acquire HPV infection was observed in some variables. HPV was lower in women over 40 years old who were married and started their first intercourse after 20 years. Likewise, IF of HPV was lower in women with more than 4 pregnancies and deliveries. 
Citation: Carrión JI, Soto Y, Escandón F, et al. (2020) Human Papillomavirus Infection and Associated Risk Factors in Indigenous and Urban Women from Cañar Province, Ecuador. J Cervical Cancer Res 3(1):307-317

Multiple infections with HPV genotypes were significantly more frequent in women of 20-30 years old, in single women and women with previous STI. HPV 16 was associated to hormonal contraceptive use during more than 2 years and inflammatory processes in cervical cytology. Meanwhile, HPV 31 was predominant in single women and those aged between 20-30 years, as it was previously reported [16].

Analysis in urban women as it has been reported before [17] demonstrated that women older than 50 years old and homemakers had lower probability to get infected by HPV. Infection frequency was substantially high in single women, those with menarche $\leq 14$ years old and with smoking habits. Previous STI, inflammatory cervical process, specifically severe process, were associated with HPV infection. Gynecological symptom related with HPV infection was vaginal discharge.

Clinical, epidemiological and socio-demographic variables were also associated to specific HPV genotypes and HPV multiple infections.

Co-infections with several HPV types were significantly frequent in women: with menarche $\leq 14$ years old; $100 \%$ (30/30), $p=0.001, \mathrm{OR}=1,57 \mathrm{Cl} 95 \%$ (1.33-1.84), hormonal contraceptive users; $70 \%(21 / 30), p=0.039, O R=2.47 \mathrm{Cl} 95 \%$ (1.00-6.14), previous STI; 50\% (15/30); $p=0.035$, OR $=2.5$ $\mathrm{Cl} 95 \%$ (1.03-6.05) and with severe inflammatory process in cervical mucosa; $23.3 \%$ (7/30); $p=0.016, \mathrm{OR}=5,02 \mathrm{Cl} 95 \%$ (1.35-18.74).

HPV 31 had higher prevalence in women with other previous STI: $58.6 \%$ (17/29), $p=0.002, \mathrm{OR}=4.17 \mathrm{Cl} 95 \%$ (1.68$10.39)$ and severe inflammatory process in cervical mucosa: $24.1 \%(7 / 29), p=0.013, \mathrm{OR}=5.33 \mathrm{Cl} 95 \%$ (1.42-19.94).

Women aged 31 to 40 years had a probability almost three times higher to be infected with HPV 58: 45.5\% (10/22), $\mathrm{p}=0.029, \mathrm{OR}=2.99 \mathrm{Cl} 95 \%(1.10-8.10)$. Also HPV 58 was predominant in professional women: $27.3 \%(6 / 22), p=0.022$, $\mathrm{OR}=4.5 \mathrm{Cl} 95 \%$ (1.28-15.78). It also was related to severe inflammatory process in cervical mucosa: $40.9 \%(9 / 22), p=$ $0.020, \mathrm{OR}=3.46 \mathrm{Cl} 95 \%(1.23-9.77)$ and vaginal discharge as gynecological symptom: $86.4 \%(19 / 22), p=0.003, O R=5.72$ Cl 95\% (1.56-20.89).

HPV 66 infection was the third more frequent HPV detected and it was associated to hormonal contraceptive use for more than 2 years. It was identifying in $53.3 \%(8 / 15)$ of positive cases; $p=0.045, O R=3.08 \mathrm{Cl} 95 \%$ (1.00-9.46).

\section{Discussion}

In Ecuador, CC is one the most frequent cancers in women population where high-risk group are in women aged 30-64 years. Currently, there are few available studies about HPV epidemiology in Ecuador $[9,15]$. This study in women from Cañar province (indigenous and urban) revealed a series of cultural, socio-demographic, clinical and epidemiological factors which significantly relates to the presence and evolution of HPV infection.

Ecuadorian women began their sexual relationships after 20 years, although previous studies have reported 15 years old as a median for both Ecuadorian genders [16]. Illiteracy or low education level, poverty and difficult to access public health services restrain to indigenous women cytological diagnostic and therefore CC early detection. As consequences, most of women under our study revealed had not been tested before our cytology study. On the other hand, the majority of Ecuadorian health institutions and private medicine have not high training level or elevated quality standards resulting in differences among the observers in Pap examinations $[17,18]$.

The recognition of one sexual partner might be explained by the social and cultural characteristics of Cañar population restricted by moral and religious rigid precepts even in the urban area [19]. In Latin America indigenous populations present similar behavior, where $50 \%$ of women of 30 years on average inform just one sexual partner. This fact demonstrates the idiosyncrasies in this ethnic [20]. However, is possible they have STI since promiscuous men conduct which is the most frequent cause of these kinds of infections $[5,21]$. These features are even more rooted in indigenous communities, where only husbands or the community leader authorize women to attend medical service, specifically gynecological examination [21].

Cytological changes in urban women presented major proportion of lesions even with 3 cases of HSIL. However, the percentage of cytological changes were into reported ranges (ASC-US: 0.6-10.4\%; LSIL, 1.8-14.5\%; HSIL, 2\%) such Ecuador as other Latin-American countries [21,22]. Conventional cytology is the main diagnostic tool used for Ecuadorian Public Health National System for CC early detection. This method, established in the network of public health services, has very low national coverage (28\%) and lack of organization and not available for all social stratus [23,24].

The frequency of HPV infection had unequal distribution between both group of women demonstrating marked social and cultural differences. Similar results have been also reported in the provinces of Guayas and Azuay from Ecuador $[5,15]$ and in other world regions, indicating that HPV prevalence drastically vary among countries and even in the same country [25].

Our research revealed the absolute predominance of oncogenic genotypes being the most frequent HPV 31, followed by HPV 16, 58 and 66, in indigenous women and HPV 58, 66 y 59 genotypes, in urban women. HPV 16 has been reported as the most frequent genotype in women from all age groups, with negative and positive cytology, from Latin-American countries and in global scale [26]. In Latin America, the circulation pattern of HPV genotypes differs in each geographical area $[27,29]$.

Studies in Ecuador have revealed dissimilar HPV genotype circulation patterns and some studies relate them with the incidence of cervical changes. Some province has reported as the most frequent $\operatorname{HR}-\operatorname{HPV}(16,52,58,59)$ and LR-HPV $(62$, 71,72 y 83) [15]. Meanwhile, others with predominance of genotypes 16 and 31 [30]. Related to cervical changes (chronic cervicitis, CIN 1 and CIN 2-3, respectively) HPV prevalence varies as HPV genotype frequency. The HPV 16 genotype is the most prevalent followed by HPV 58 [31]. HPV 18 genotype 
Citation: Carrión JI, Soto Y, Escandón F, et al. (2020) Human Papillomavirus Infection and Associated Risk Factors in Indigenous and Urban Women from Cañar Province, Ecuador. J Cervical Cancer Res 3(1):307-317

had been showed the highest incidence, especially in women with pre-cancer vaginal and cervical lesions, and cervical cancer [32].

Relationship between HPV co-infections and cervical lesions up to develop CC has been established [33]. It is also associated multiple infections and cytological changes, nonuse of condom and higher number sexual partners which are commonly observed in women with multiple infections with HR-HPV compared to simple infections with LR-HPV [34]. Although the role of multiple infections is questioned in women with premalignant lesions, it have been reported that number of genotypes detected decline with severity of lesions [35]. This result was documented in our study despite its limitations.

HPV multiple infections in women have been also associated with the risk to develop $\mathrm{CC}$, particularly when viral load is $>10^{3}$ copies $/ \mathrm{mL}$ in LSIL, between $10^{5}$ y $10^{7}$ copies $/ \mathrm{mL}$ in HSIL and insitu carcinoma [36]. Consequently, viral load has been considered as progression and severity marker in HPV infection evolution, $[37,38]$. Genotype specific viral load and integration status of HPV 16, 18 and 58 are reported as diagnostic biomarkers of high grade cervical intraepithelial lesions and CC [39]. According to this criterion, our results suggest that women infected with oncogenic genotypes have a high probability to develop persistent infections and precursors lesions of CC.

There are others markers which allow characterize HRHPV infections and contributing to cervical lesion evolution and cervical cancer. Social, cultural, demographic, clinical and epidemiological variables are also associated to HPV infection, presence and evolution of cervical intraepithelial lesions [40]. Concerning to socio-demographic and clinical-epidemiological variables associated to HPV infection, the present work found in young indigenous women (20-30 years) 5 more times probabilities to be infected. Meanwhile, urban women $>50$ years had less probabilities to be infected regarding all women studied; which was analogous to international literature $[40,41]$. On the other hand, HPV acquisition is common in teenagers and young women in the first intercourse and HR-HPV and cervical lesions are temporary and also disappear with age $[42,43]$. However, in our research we did not find this behavior in urban women. There were not differences in the IF of HPV among all age groups. Additional reports in Ecuadorian women had described similar results where the infection even discreetly increases among women of 40-50 years old [15]. Probably, HPV infection with new genotypes or possible persistent infections may explain this behavior. However, it just can be confirmed if positive previous evidences with same HPV genotypes identified at the moment of the research.

One relevant finding in our work was the association of HPV infection and cigarettes consumption and hormonal contraceptive use, particularly in urban women demonstrating a typical metropolises behavior. Socio-demographic and clinical-epidemiological variations among different regions of the same country depend on sociocultural and conducts of their resident women. They influence, in this case, in the practice of toxic habits as cigarettes consumption and contraceptive hormonal treatments [44-45].
The high prevalence of HR-HPV infection suggests the necessity to incorporate Cañar population in CC early detection programs and to promote health campaigns in order to prevent SIT and improve sexual and reproductive education. Since these findings relied on small number of cases, further studies with large number of cases may be of significance to support these findings.

\section{References}

1. Harald zur Hausen (2009) Papillomaviruses in the causation of human cancers - a brief historical account. Virology 384: 260265.

2. Bruni L, G Albero, B Serrano, et al, (2019) Human papillomavirus and related diseases in the world. In: ICO/IARC. Information Centre on HPV and Cancer (HPV Information Centre). Summary Report, Institut Català d'Oncologia: Barcelona, Spain.

3. Melinte-Popescu A, G Costachescu (2012) The degree of agreement between HPV testing, pap smear and colposcopy in cervical dysplasia diagnosis. Rev Med Chir Soc Med Nat lasi 116: 536-539.

4. Catherine de Martel, M Plummer, J Vignat, et al. (2017) World wide burden of cancer attributable to HPV by site, country and HPV type. Int J Cancer 141: 664-670.

5. Bedoya-Pilozo CH, LG Medina Magues, M Espinosa-Garcia, et al. (2018) Molecular epidemiology and phylogenetic analysis of human papillomavirus infection in women with cervical lesions and cancer from the coastal region of Ecuador. Rev Argent Microbiol 50: 136-146.

6. Mejia L, D Munoz, G Trueba, et al. (2016) Prevalence of human papillomavirus types in cervical cancerous and precancerous lesions of Ecuadorian women. J Med Virol 88: 144-152.

7. Mancilla JC (2013) Public expenditure in health in Ecuador Pathologica. 103: 53-60.

8. SOLCA BE (2017) Incidencia de cáncer en el Hospital de SOLCA de Guayaquil, 2013-2017, INEC-MSP, SOLCA: Guayaquil, Ecuador, 1-12.

9. Cabrera JA, OJ Cárdena, MA Campoverde, et al. (2015) Prevalencia de genotipos del papiloma virus humano en mujeres de la provincia del Azuay, Ecuador. MASKANA 6: 79-93.

10. Dalgo Aguilar P, C Lojan Gonzalez, A Cordova Rodriguez, et al. (2017) Prevalence of high-risk genotypes of human papillomavirus: Women diagnosed with premalignant and malignant pap smear tests in southern Ecuador. Infect Dis Obstet Gynecol 2017: 8572065.

11. Asotic A, S Taric, J Asotic (2014) Correlation of cervical smear and pathohistological findings. Med Arch 68: 106-109.

12. Van Delden J, R Van der Graaf (2016) Revised CIOMS international ethical guidelines for health-related research involving humans. JAMA 317: 135-136.

13. Ritu N, DC Wilbur (2014) The bethesda system for reporting cervical cytology. ( $3^{\text {rd }}$ edn), Definitions, Criteria, and Explanatory Notes, Springer, Chicago, IL, USA, 342.

14. Bouvard V, R Baan, K Straif, et al. (2009) A review of human carcinogens--Part B: Biological agents. Lancet Oncol 10: 321-322.

15. Carrión-Ordóñez JI, Y Soto-Brito, M Pupo-Antúnez, et al. (2019) Infección por Virus del Papiloma Humano y citología cérvico-vaginal en mujeres indígenas del Cañar, Ecuador. Bionatura 4: 934-938. 
Citation: Carrión JI, Soto Y, Escandón F, et al. (2020) Human Papillomavirus Infection and Associated Risk Factors in Indigenous and Urban Women from Cañar Province, Ecuador. J Cervical Cancer Res 3(1):307-317

16. Carrión-Ordóñez JI, Y Soto-Brito, M. Pupo-Antúnez (2020) Alta frecuencia de infección por virus del papiloma humano en mujeres del cañar, Ecuador. Rev. Cub. Med. Trop 72: e500.

17. Brown CR, ML Leon, K Munoz, et al. (2009) Human papillomavirus infection and its association with cervical dysplasia in Ecuadorian women attending a private cancer screening clinic. Braz $J$ Med Biol Res 42: 629-636.

18. Jaruseviciene L, M Orozco, M Ibarra, et al. (2013) Primary healthcare providers' views on improving sexual and reproductive healthcare for adolescents in Bolivia, Ecuador, and Nicaragua. Glob Health Action 6: 20444.

19. (2006) Programa nacional de salud reproductiva: Componente cérvico-uterino. Manual para tamizaje del cáncer cérvico-uterino, M.d.S.P.y.A. Social, Ministerio de Salud Pública: Ecuador.

20. Guía Clínica Cáncer cervico-uterino (2010) C Minsal, guías clínicas NINSAL: Santiago de Chile.

21. Muñoz G, L Mota, WR Bowie, et al. (2011) Ecosystem approach to promoting appropriate antibiotic use for children in indigenous communities in Ecuador. Rev Panam Salud Publica 30: 566-573.

22. Mendoza L, P Mongelos, M Paez, et al. (2013) Human papillomavirus and other genital infections in indigenous women from Paraguay: A cross-sectional analytical study. BMC Infect Dis 13: 531.

23. Nugus P, J Desalliers, J Morales, et al. (2018) Localizing global medicine: Challenges and opportunities in cervical screening in an indigenous community in Ecuador. Qual Health Res 28: 800-812.

24. Moore SP, D Forman, M Pineros, et al. (2014) Cancer in indigenous people in Latin America and the Caribbean: A review. Cancer Med 3: 70-80.

25. Badano I, SM Stietz, TG Schurr, et al. (2012) Analysis of TNF alpha promoter SNPs and the risk of cervical cancer in urban populations of Posadas (Misiones, Argentina). J Clin Virol 53: 54-59.

26. Carozzi F, L De Marco, A Gillio-Tos, et al. (2014) Age and geographic variability of human papillomavirus high-risk genotype distribution in a large unvaccinated population and of vaccination impact on HPV prevalence. J Clin Virol 60: 257-263.

27. Bruno A, K Serravalle, AG Travassos, et al. (2014) Genotype distribution of human papillomavirus in women from the state of Bahia, Brazil. Rev Bras Ginecol Obstet 36: 416-422.

28. Gonzalez-Andrade F, D Sanchez (2009) HPV genotyping in anogenital abnormal samples of Ecuadorian women. Cancer Biomark 5: 225-232.

29. Tornesello ML, L Buonaguro, S Izzo, et al. A pilot study on the distribution of human papillomavirus genotypes and HPV-16 variants in cervical neoplastic lesions from Ecuadorian women. J Med Virol 80: 1959-1965.

30. Alemany L, M Saunier, L Tinoco, et al. (2014) Large contribution of human papillomavirus in vaginal neoplastic lesions: A worldwide study in 597 samples. Eur J Cancer 50: 2846-2854.

31. Wentzensen N, M Schiffman, T Dunn, et al. (2009) Multiple human papillomavirus genotype infections in cervical cancer progression in the study to understand cervical cancer early endpoints and determinants. Int J Cancer 125: 2151-2158.
32. De Brot L, B Pellegrini, ST Moretti, et al. (2017) Infections with multiple high-risk HPV types are associated with high-grade and persistent low-grade intraepithelial lesions of the cervix. Cancer Cytopathology 125: 138-143.

33. lacobone AD, F Bottari, D Radice, et al. (2019) Distribution of high-risk human papillomavirus genotypes and multiple infections in preneoplastic and neoplastic cervical lesions of unvaccinated women: A cross-sectional study. J Low Genit Tract Dis 23: 259-264.

34. Schmitt M, C Depuydt, I Benoy, et al. (2013) Multiple human papillomavirus infections with high viral loads are associated with cervical lesions but do not differentiate grades of cervical abnormalities. J Clin Microbiol 51: 1458-1464.

35. Oyervides-Muñoz MA, AA Pérez-Maya, CN Sánchez-Domínguez, et al. (2020) Multiple HPV infections and viral load association in persistent cervical lesions in mexican women. Viruses 12: 380.

36. Scarpini CG, IJ Groves, MR Pett, et al. (2014) Virus transcript levels and cell growth rates after naturally occurring HPV16 integration events in basal cervical keratinocytes. J Pathol 233: 281-293.

37. Kim J, BK Kim, D Jeon, et al. (2020) Type-specific viral load and physical state of HPV type 16, 18, and 58 as diagnostic biomarkers for high-grade squamous intraepithelial lesions or cervical cancer. Cancer Res Treat 52: 396-405.

38. Del Rio-Ospina L, SC Soto de Leon, M Camargo, et al. (2017) Multiple high-risk HPV genotypes are grouped by type and are associated with viral load and risk factors. Epidemiol Infect 145: 1479-1490.

39. Vaccarella S, J Lortet-Tieulent, M Plummer, et al. (2013) Worldwide trends in cervical cancer incidence: impact of screening against changes in disease risk factors. Eur J Cancer 49: 3262-73.

40. Barrios L, I Benedetti, L Alvis, et al. (2011) Conocimientos, actitudes y prácticas sobre la citología cérvico-uterina en mujeres de Sincelejo y Cartagena, Colombia. Rev Cienc Biomed 2: 249-255.

41. Wang Y, YH Yu, K Shen, et al. (2014) Cervical cancer screening and analysis of potential risk factors in 43,567 women in zhongshan, China. Asian Pac J Cancer Prev 15: 671-676.

42. Smith EM, JM Ritchie, BT Levy, et al. (2003) Prevalence and persistence of human papillomavirus in postmenopausal age women. Cancer Detect Prev 27: 472-480.

43. Banister CE, AR Messersmith, H Chakraborty, et al. (2013) HPV prevalence at enrollment and baseline results from the carolina women's care study, a longitudinal study of HPV persistence in women of college age. Int J Womens Health 5: 379-388.

44. Jordá GB, JM Ramos, J Mosmann, et al. (2020) Prevalence of human papillomavirus and associated risk factors in women affiliated with state health insurance in posadas, misiones (Argentina). Rev Chilena Infectol 37: 111-116.

45. Wang CP, TC Chen, HH Chen, et al. (2019) Prevalence of current oral HPV infection among 100 betel nut chewers or cigarette smokers in Northern Taiwan. J Formos Med Assoc 118: 203-208.

46. Adhikari I, T Eriksson, T Luostarinen, et al. (2018) The risk of cervical atypia in oral contraceptive users. Eur J Contracept Reprod Health Care 23(1): 12-17.

DOI: $10.36959 / 749 / 522$

Copyright: (c) 2020 Carrión Jl, et al. This is an open-access article distributed under the terms of the Creative Commons Attribution License, which permits unrestricted use, distribution, and reproduction in any medium, provided the original author and source are credited. 